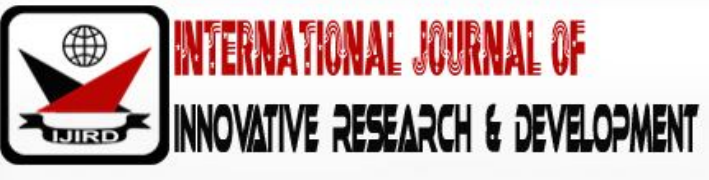

ISSN 2278 - 0211 (Online)

\section{Ghana's Human Rights Record and Equal Protection from Violence to All Citizens}

\author{
William Nyarko \\ Executive Director, Department of Office of the Executive Director, \\ Africa Centre for International Law and Accountability (ACILA), Ghana \\ Kojo Impraim \\ Head, Department of Policy and Research Unit, \\ Africa Centre for International Law and Accountability (ACILA), Ghana
}

\begin{abstract}
:
The paper sought to examine Ghana's human rights record and the treatment of vulnerable groups. It particularly assesses popular attitudes towards the sexual orientation of Lesbians, Gays, Bisexuals, Transgender and Intersexuals (LGBTIs), and why people hold certain attitudes towards same-sex relations in Ghana. The study was descriptive with a representative sampling from five regions namely, Greater Accra, Ashanti, Northern, Volta and Western. A sample size of 1200 with 95\% confidence level and a margin of error of $+/-2.8$ was employed. The study revealed divergent findings about the perceptions, attitudes, knowledge, opinions and values of citizens on LGBTI issues in Ghana. First, while results showed that $87 \%$ of Ghanaians say they understand the fundamental human rights provisions in the 1992 Constitution of Ghana, the same percentage of Ghanaians (87\%) are against allowing LGBTIs from holding public meetings. Similarly, about $60 \%$ of Ghanaians "strongly disagree" or "disagree" LGBTIs deserve equal treatment as heterosexuals. In addition, even though more than $97 \%$ of Ghanaians are aware that the Police have a responsibility to protect every citizen against mob injustice, only $20 \%$ "strongly disagree" or "disagree" the Police have a responsibility to protect LGBTIs against mob injustice.

The study also established a strong correlation between religion and the rights of LGBTIs, with religion being a major predictor and significantly influencing people's attitudes towards LGBTIs.

In 2017, Ghana accepted a number of recommendations under the Universal Period Review (UPR) from the United Nations Human Rights Council (UNHRC) to provide equal protection of the law from violence to all persons including the sexual orientation of LGBTIs. The findings of the study were intended to monitor Government commitment to the implementation of the UPR recommendations. The study recommends the following among others: that public education of the understanding of the distinction between the rights and perceived acts of LGBTIs is crucial to the equal protection of the law from violence and discrimination to LGBTIs.
\end{abstract}

Keywords: Human rights, equal protection, sexual orientation, universal period review, vulnerable groups, LGBTI, violence, discrimination

\section{Introduction}

Chapter 5 of the 1992 Constitution of Ghana guarantees the fundamental human rights and freedoms to every Ghanaian. Article 12 clause (2) of the Chapter indicates that "every person in Ghana... shall be entitled to fundamental human rights and freedom but subject to respect for the rights and freedoms of others, and for the public interest" (Republic of Ghana, 1992). These rights shall be upheld by the executive, legislature, judiciary, and other quasi human rights arbiters.

One of such rights entitled to all persons is sexual rights. The World Health Organisation explains that "sexual rights embrace human rights that are already recognised in national laws, international human rights documents and other consensus statements" (WHO, 2012). These include the right of all persons, free of coercion, discrimination and violence, to: (1) the highest attainable standard of sexual health, including access to sexual and reproductive health care services; (2) seek, receive and impart information related to sexuality; (3) sexuality education; (4) respect for bodily integrity; and (5) chose their partner (Ibid).

The court of public opinion has become a major platform for discussing the sexual orientation of vulnerable persons such as LGTBIs. For example, through the electronic and print media, publications on LGBTI issues have tended to be stereotypically imagery (Allotey citing Quist-Adade, et al.; 2014; Epprecht 2013; Ofori, 2014; Murray and Roscoe, 1998). This posturing often sparks one-sided public discussion on LGBTI issues and contributes to the perpetration of violence, discrimination, and marginalization of LGBTIs. 
On November 7, 2017, Ghana appeared before the UN Human Rights Council (UNHRC) for a review of its human rights record under the Universal Periodic Review mechanism. During the review and follow up discussion by the Working Group, Ghana rejected (noted) recommendations to legalize same-sex marriage or decriminalize consensual sexual relations but accepted recommendations to provide Equal Protection of the Law from violence and discrimination against LGBTIs in accordance with Ghana's domestic law and international human rights law obligations.

In order to ensure effective monitoring and implementation of this recommendation, the Africa Centre for International Law and Accountability (ACILA) a research and education, and not-for-profit-based organisation in Ghana which monitors commitments made by African states, including Ghana, commissioned a study to assess popular attitudes of Ghanaians towards LGBTI issues. Hitherto, there was no comprehensive scientific public opinion data to gauge Ghanaians' attitudes towards LGBTI issues and engender informed discussion for effective policymaking. This article fills this gap by analyzing the perceptions, views, values and attitudes people hold towards LGBTI issues, and their implications for discussions in Ghana and at the international level. Also, the research findings will inform public advocacy and monitoring of Government's commitment to upholding the fundamental human rights and freedoms of all citizens as enshrined in the 1992 Constitution of Ghana. The study used a representative sampling from five regions of Ghana.

\subsection{Objectives of the Study}

The objectives of the study were to:

- Provide comprehensive scientific public opinion data to engender informed discussions on same-sex relations and their implications for policymaking.

- Use the findings to monitor Ghana's commitments to provide equal protection of the law from violence and discrimination for vulnerable groups including LGBTIs.

\subsection{Research Questions}

- Why do people hold attitudes or shape their attitudes towards same-sex relations in Ghana?

- What are the driving factors of stigmatization and violence against the sexual orientation of LGBTIs?

\subsection{Significance of the Study}

First, the study sought to create a nationwide empirical data to inform public discourse on same-sex orientation in Ghana. Second, it sought to assess popular attitudes towards sexual orientation of vulnerable groups such as LGBTIs. Third, the study sought to monitor Ghana's commitment under the UPR to protect the fundamental human rights and freedoms of all persons as a constitutional requirement. Finally, contribute to the theoretical and empirical literature on sexual orientation of LGBTIs.

\section{Overview of Literature}

\subsection{Fundamental Human Rights for All: What is it?}

The State has a duty to protect, respect, and protect the inalienable rights of its citizens. Human rights reckon the individual as the principal object of concern (Sen, 2000). Individual rights are inviolable and boundary marks which the state is expressly forbidden from interfering with. Rights appear open-and-endless encompassing everything from physical rights to psychological well-being of the individual (Singh, 2014). Human rights also connote human security. The 1994 United Nations Development Programme (UNDP) Human Development Report defines human security as "people's safety from chronic threats and protection from sudden hurtful disruptions in the patterns of daily life". The report advances that "insuring 'freedom from want' and 'freedom from fear' for all persons is the best path to tackle the problem of insecurity and safety of the individual" (UNDP, 1994). Fundamental human rights of the individual presage liberalism, and liberalism is individualistic. It means freedom - the absence of coercion in one's life. To be a liberal person in a democratic society, explicitly connotes being allowed to do anything so long as it does not harm or infringe on the liberties of others.

Hayek indicates that "coercion is the control of the environment or circumstances of a person by another such that in order to avoid greater evils, the individual is forced to act not in accordance with a coherent plan of his own but to serve the ends of others" (Hayek, 1967; Hayek, 1960; Daumann, 2007: 123-50). Equally, Berlin gives an impression that "I am normally said to be free to the degree that no man or body of men interferes with my activity" (Berlin, 1959). Both Hayek and Berlin want us to be aware that fundamental human rights and freedom of the individual can be productive and collectively ensure the survival of the State. Thus, human rights are universal, human-centred and reinforce the primacy of individual's choices in life.

The 1992 Constitution of Ghana makes it the responsibility of state institutions to protect the rights of citizens. The organs of government, other quasi-legal and human rights arbiters including the Ghana Police Service (GPS), the Commission on Human Rights and Administrative Justice (CHRAJ), and the courts are, for example, the first point of call when the rights of citizens are abused. Often, the practice of "majoritarianism" in democratic states subsumes the rights of minorities, where the former expects the latter to conform to pre-determined status-quo. But the efficacy of the majority principle must as well seek to protect the rights and welfare of the minorities in the society.

Discussions on same-sex orientation has in recent times gained prominence in bilateral and multilateral discourse (BBC, 2018; Aljazeera, 2018), and sometimes prospectively threatens development co-operation between developed and developing nations. Besides, several citizens have expressed sentiments about the sexual orientations of LGBTIs, 
particularly in Africa, and more so in Ghana. The exercise of human rights and freedoms of the individual in a democratic State requires that all persons respect the rights of others.

\subsection{Ghana's Obligations under International Human Rights Law and Protection of LGBTIs}

Discussions about the sexual orientation of LGBTIs continue, with great variations in public opinion about its acceptability, repeal of discriminatory laws, laws regulating same-sex unions and sexual behaviours (Adamczyk and Pitt, 2009). Due to increasing victimization and attacks on the rights of minorities identified as LGBTIs, the UNHRC in 2011, adopted a resolution on human rights, sexual orientation, and gender identity to protect the rights of such individuals (UNHCR, 2017). In Ghana, discussions on the rights of LGBTIs have mostly centred on legal provisions, particularly, section 104 (1) (b) of the Criminal Code Act, 2003 which prohibits unnatural carnal knowledge (Ghana, 1960 Criminal Act; Constitutional Review Commission report, 2010). Arguably this provision has been misrepresented as criminalizing gay and lesbian orientation.

Article 75 (1) of the 1992 Constitution of Ghana states that "the President may execute or cause to execute treaties, agreements, or conventions in the name of Ghana. Ghana is also a State Party to a number of regional and international human rights instruments which place an obligation on the state to ensure, respect, promote, and protect the fundamental human rights of all persons. In November 2017, Ghana accepted a number of recommendations from the UNHCR under the UPR to - a) Take the steps necessary to protect LGBTI persons from violence and discrimination on the basis of their sexual orientation and gender identity [Ireland]; b) Ensure that victims of discrimination and violence based on sexual orientation and gender identity have access to rehabilitation and remedy and that all perpetrators are punished [Czechia]; c) Take measures to fight against violence and discrimination based on sexual orientation and gender identity [Italy]; d) Continue to implement the discrimination reporting system in order to tackle stigmatization and discrimination of the most vulnerable groups [Bolivarian Republic of Venezuela], among others. Ghana, however, noted (rejected) recommendations to legalize same-sex marriage or decriminalize consensual same-sex relations (UNHRC, 2017).

Also, following Ghana's ratification of the First Optional Protocol to the International Covenant on Civil and Political Rights (ICCPR), individual citizens whose human rights are violated can file a complaint against the State at the United Nations Human Rights Committee. Further, Ghana has ratified and made a declaration under the Protocol to the African Charter on Human and Peoples' Rights allowing individuals to file a complaint against the State to seek redress of human rights abuses (State of the Union Report, 2010). Article 6 of the Charter states that "every individual shall have the right to liberty and personal security. No one may be deprived of his freedom except for reasons and conditions previously laid down by law" (Ibid). Equally, Article 17 of the 1992 Constitution of Ghana states that "all persons shall be equal before the law and that no one shall be discriminated against on basis of gender, race, colour, ethnicity, religion and creed, social or economic status" (Republic of Ghana, 1992 Constitution).

Evidence suggests that LGBTIs in Ghana are often subjected to discrimination, intimidation, verbal and physical abuses (UNHRC, 2017). Further, the Humanist Association of Ghana argues that attempts have been made by some sections of the society to humiliate, dehumanize, perpetuate act of violence and even threaten death against LGBTIs based on their sexual orientation (Humanist Association of Ghana, 2017). Also, the US Human Rights Country report highlights that LGBTIs face widespread discrimination in employment and education, as well as police harassment in Ghana. A climate of homophobia largely inhibits LGBTIs from reporting violations of their fundamental human rights for fear of being arrested (Amnesty International Ghana, 2018; UPR, 2017; ACILA project document, 2018).

\subsection{The Universal Period Review (UPR) and Ghana's Obligations of Equal Protection to All}

The UPR was created as a cooperative mechanism through the UN General Assembly on 15 March 2006 by resolution 60/ 251 (UNHCR, 2010; ICHR, 2009). Through this mechanism, Member States systematically and periodically scrutinize the fulfillment of the obligations of Member States. The review is a state-driven process carried out through open, tolerant, cooperative and a consensual manner among the States (UNHRC, 2014; UNHCR UPR, 2008; Friedrich Ebert Stiftung, 2008). The UPR primarily reminds Member States of their responsibility to fully respect and implement all incountry and international laws on human rights and fundamental freedoms in order to improve the human rights situations, thereby addressing acts of violations against citizens' rights and freedom wherever they occur. In the words of Ban Ki-moon, "the mechanism has great potential to promote and protect human rights in the darkest corners of the world" (Ban Ki-moon, OHCHR 2008).

The UPR is executed based on three documents- a) a national report prepared by the State under review, b) a compilation of UN information on the State under review prepared by OHCHR, and c) a summary of information submitted by other stakeholders (including civil society actors), also prepared by OHCHR. The UPR process also assesses the extent to which Member States respect human rights obligations contained in- (a) The United Nations Charter, b) The Universal Declaration of Human Rights, c) UN Treaties on Human Rights, d) Human rights instruments (covenants, conventions and other treaties) to which the State is a party, e) voluntary pledges and commitments made by the State, and e) applicable international humanitarian law. In November 2017, Ghana appeared before the UNHCR for a review of its human rights record under the UPR and accepted the following recommendations to provide equal protection of the law for all persons including members of the LGBTI community (UNHRC, 2017). That Ghana:

- 146.59: should take the steps necessary to protect LGBTI persons from violence and discrimination on the basis of their sexual orientation and gender identity (by Ireland),

- 146.60: should ensure that victims of discrimination and violence based on sexual orientation and gender identity have access to rehabilitation and remedy and that all perpetrators are punished (by Czechia), 
- 146.61: should take measures to fight against violence and discrimination based on sexual orientation and gender identity that the UN declaration (by Italy), and

- 146.63: should continue to implement the discrimination reporting system in order to tackle stigmatization and discrimination of the most vulnerable groups (by Bolivarian Republic of Venezuela).

- Ghana however, rejected recommendations to legalise same-sex relation

It suffices to say from the above reviews that, little or no empirical study had been carried out on Ghana's human rights record and commitment to providing equal protection of the law from violence and discrimination to all citizens including vulnerable groups such as LGBTIs. This article therefore fills the literature gap by offering a contextual analysis of the equal protection of vulnerable groups in the society. It specifically assesses people's perceptions and attitudes towards LGBTI issues, and the driving factor(s) that shape public discourse on LGBTI.

\section{The Methodology}

The study adopted a mixture of research methodology that was mainly descriptive. The choice helped in overcoming weaknesses of lack of rigour, sturdiness and single method approach of the survey. The study was a representative sampling of five regions namely Greater Accra, Ashanti, Northern, Volta and Western.

As is the case in all probability sampling surveys, it was important that primary sampling units (PSUs) was established so that all population had a known, and non-zero probability of selection. At the first stage was the selection of 107 Enumerated Areas (EAs) made up of a total list of all localities within the five selected regions, using the nationwide enumerated areas from the Ghana Statistical Service (GSS) (Ghana Statistical Service, 2013b). Refer to Table 1: At the second stage, a total of 1200 responses were sampled. This sample was selected at the confidence level of $95 \%$ and margin of error of $+/-2.8 \%$ across the five regions. Refer to Table 2.

In order to take advantage of possible gains in precision and reliability of the survey estimates from stratification, the Stratification and Sample Allocation (SDPs) were first stratified into the five administrative regions. Within each region, the EAs were further sub-divided yielding a total of nine (9) sampling strata. Samples were selected independently in each sampling stratum, by a one-stage selection using systematic sampling method. Due to the non-proportional allocation of the sample to the different regions and the possible differences in response rates, sampling weights was computed for the analysis to ensure the actual representation of the survey results at the regional level. It is important to note that this was not a self-weighting sample design; hence, weights were computed for each respondent, in order to obtain the true contribution of selected respondent in the sample based on the first and second stage probabilities of selection (Lindlof, and Taylor, 2010).

The data for the study was collected within two months from May to June 2018. Data were collected through questionnaire administration with the help of Field Research Assistants (FRA) recruited from each region, as a strategy to localize questionnaire administration. This approach was adopted because it assisted in dealing with the potential language barrier. The questionnaire administration was anonymized using 3 Sky 4 G LTE devices. These processes largely contributed to enhancing the credibility of the research findings. Questionnaires were administered to males, females and transgender (Patton, 1987; Flick, 2009; Beeke 1995).Every adult citizen of voting age 18 years and older had an equal chance of being selected.

\begin{tabular}{|c|c|c|c|}
\hline Region & EAs & Urban & Peri-Urban/ Rural \\
\hline Greater Accra & 25 & 25 & 0 \\
\hline Ashanti & 35 & 29 & 6 \\
\hline Northern & 20 & 7 & 13 \\
\hline Volta & 12 & 12 & 12 \\
\hline Western & 15 & 11 & 4 \\
\hline Total & 107 & 72 & 35 \\
\hline
\end{tabular}

Table 1: Allocation of EAS by Locality of Residence

Source Ghana Statistical Service, 2018

\begin{tabular}{|c|c|c|c|c|c|}
\hline \multicolumn{2}{|c|}{} & Frequency & Percent & $\begin{array}{c}\text { Valid } \\
\text { Percent }\end{array}$ & $\begin{array}{c}\text { Cumulative } \\
\text { Percent }\end{array}$ \\
\hline \multirow{7}{*}{ Valid } & $\begin{array}{c}\text { Greater } \\
\text { Accra }\end{array}$ & 300 & 25.0 & 25.0 & 25.0 \\
\cline { 2 - 6 } & Ashanti & 360 & 30.0 & 30.0 & 55.0 \\
\cline { 2 - 6 } & Northern & 180 & 15.0 & 15.0 & 70.0 \\
\cline { 2 - 6 } & Volta & 180 & 15.0 & 15.0 & 85.0 \\
\cline { 2 - 6 } & Western & 180 & 15.0 & 15.0 & 100.0 \\
\cline { 2 - 6 } & Total & 1200 & 100.0 & 100.0 & \\
\hline
\end{tabular}

Table 2: Regional Sample Size of the Respondents

Source: Fieldwork, May to June, 2018 


\section{Results and Findings}

The findings of the study highlight the opinions of Ghanaians on the protection of vulnerable groups such as LGBTI under equal protection of the law from violence and discrimination. It also provided data on issues such as citizens' knowledge of the law, attitudes and perceptions, comfort and association, tolerance, acts of mob injustice, institutional responsibility and homophobic/hate statements. In this study the terms: Lesbian, Gay, Bisexual, Transgender, and Intersexual (LGBTI) people, Homosexuality and same-sex relationship or marriage shall mean the same thing to avoid confusion. Homosexuality encompasses a variety of phenomena related to same-sex sexual orientation. Heterosexuality on the other hand is a form of sexual orientation in which individuals of the opposite sex are attracted to each other and derive erotic needs satisfaction (Herek, 2000a; 2000b; Herek, 1988; Herek).

\subsection{Citizens' Knowledge of the 1992 Constitution and Human Rights Issues}

A high percentage (87.2\%) of the respondents knew that the 1992 Constitution of Ghana guarantees human rights to all persons in Ghana. Refer to Table 3.

\begin{tabular}{|c|c|c|c|c|}
\hline \multicolumn{2}{|c|}{} & Yes & No & \\
\hline \multirow{3}{*}{$\begin{array}{c}\text { Region } \\
:\end{array}$} & GreaterAccra & $86.3 \%$ & $13.7 \%$ & $100.0 \%$ \\
\cline { 2 - 5 } & Ashanti & $82.2 \%$ & $17.8 \%$ & $100.0 \%$ \\
\cline { 2 - 5 } & Northern & $83.3 \%$ & $16.7 \%$ & $100.0 \%$ \\
\cline { 2 - 5 } & Volta & $91.7 \%$ & $8.3 \%$ & $100.0 \%$ \\
\cline { 2 - 5 } & Western & $97.8 \%$ & $2.2 \%$ & $100.0 \%$ \\
\hline \multicolumn{2}{|c|}{ Total } & $87.2 \%$ & $12.8 \%$ & $100.0 \%$ \\
\hline
\end{tabular}

Table 3: Knowledge Level of Citizens of1992

Constitution Regarding Human Rights Issues

Source: Fieldwork, May to June 2018

\subsection{Citizens' Knowledge of LGBTI Issues and Persons in Ghana}

Approximately $96 \%$ of the citizens have heard about LGBTI issues in Ghana. The medium through which information of LGBTI was disseminated was the radio (85.6\%), followed by Television (8.7\%), Internet (2.2\%) and interpersonal relationships (1.2\%). Approximately 13\% of citizens know LGBTI person who live in their community and/ or in Ghana with Western region registering the highest (21.7\%). The findings corroborate Allotey's assertion that Ghanaians are not mainly heterosexuals, other forms of sexual orientations such as homosexuality exist which is practiced both secretly and in open spaces (Allotey, 2015). Refer to Table 4:

\begin{tabular}{|c|c|c|c|c|}
\hline \multicolumn{2}{|c|}{} & Yes & No & \\
\hline \multirow{3}{*}{ Region: } & Greater Accra & $13.7 \%$ & $86.3 \%$ & $100.0 \%$ \\
\cline { 2 - 5 } & Ashanti & $14.4 \%$ & $85.6 \%$ & $100.0 \%$ \\
\cline { 2 - 5 } & Northern & $6.7 \%$ & $93.3 \%$ & $100.0 \%$ \\
\cline { 2 - 5 } & Volta & $5.6 \%$ & $94.4 \%$ & $100.0 \%$ \\
\cline { 2 - 5 } & Western & $21.7 \%$ & $78.3 \%$ & $100.0 \%$ \\
\hline \multicolumn{2}{|c|}{ Total } & $12.8 \%$ & $87.2 \%$ & $100.0 \%$ \\
\hline
\end{tabular}

Table 4: Citizens Knowledge of LGBTI Persons in the Community

Source: Fieldwork, May to June 2018

\subsection{Citizens' Knowledge of the Universal Periodic Review (UPR) Mechanism}

A high number of the study population, $60.7 \%$ are not aware that Ghana has committed itself to the United Nations' Universal Periodic Review mechanism established in 2006. Refer to Table 5.

\begin{tabular}{|c|c|c|c|c|c|}
\hline \multicolumn{2}{|c|}{} & Frequency & Percent & $\begin{array}{c}\text { Valid } \\
\text { Percent }\end{array}$ & $\begin{array}{c}\text { Cumulative } \\
\text { Percent }\end{array}$ \\
\hline Valid & Yes & 472 & 39.3 & 39.3 & 39.3 \\
\cline { 2 - 6 } & No & 728 & 60.7 & 60.7 & 100.0 \\
\cline { 2 - 6 } & Total & 1200 & 100.0 & 100.0 & \\
\hline
\end{tabular}

Table 5: Awareness Level of the UPR Mechanism by the Citizens

Source: Fieldwork, May to June 2018

\subsection{Tolerance Level of Heterosexuals towards LGBTI Persons}

High level of intolerance (45.3\%) was registered among Ghanaians across the study regions. Only $18.8 \%$ of the respondents indicated that they would treat an identified LGBTI "just like any heterosexual: Refer to Table 7. 


\begin{tabular}{|c|c|c|c|c|c|c|c|c|}
\hline & $\begin{array}{l}\text { Treat Him Or } \\
\text { Her Just Like } \\
\text { Any } \\
\text { Heterosexual }\end{array}$ & $\begin{array}{c}\text { Verbally } \\
\text { Abuse } \\
\text { Him Or } \\
\text { Her }\end{array}$ & $\begin{array}{c}\text { Physically } \\
\text { Abuse } \\
\text { Him Or } \\
\text { Her }\end{array}$ & $\begin{array}{c}\text { Socially } \\
\text { Shun } \\
\text { Him Or } \\
\text { Her }\end{array}$ & $\begin{array}{c}\text { Force } \\
\text { Him/ Her } \\
\text { To Hide } \\
\text { His/ Her } \\
\text { Identity }\end{array}$ & $\begin{array}{l}\text { Other, } \\
\text { Please } \\
\text { Specify }\end{array}$ & \\
\hline \multirow[t]{5}{*}{ Region: } & $\begin{array}{c}\text { Greater } \\
\text { Accra }\end{array}$ & $27.3 \%$ & $5.3 \%$ & $2.7 \%$ & $37.0 \%$ & $4.7 \%$ & $23.0 \%$ & $100.0 \%$ \\
\hline & Ashanti & $16.9 \%$ & $3.6 \%$ & $4.4 \%$ & $41.9 \%$ & $1.4 \%$ & $31.7 \%$ & $100.0 \%$ \\
\hline & Northern & $16.1 \%$ & $4.4 \%$ & $.6 \%$ & $58.9 \%$ & $10.0 \%$ & $10.0 \%$ & $100.0 \%$ \\
\hline & Volta & $13.3 \%$ & $6.7 \%$ & $5.0 \%$ & $57.2 \%$ & $12.2 \%$ & $5.6 \%$ & $100.0 \%$ \\
\hline & Western & $16.7 \%$ & $3.3 \%$ & $2.8 \%$ & $40.0 \%$ & $1.1 \%$ & $36.1 \%$ & $100.0 \%$ \\
\hline \multicolumn{2}{|c|}{ Total } & $18.8 \%$ & $4.6 \%$ & $3.3 \%$ & $45.3 \%$ & $5.1 \%$ & $23.0 \%$ & $100.0 \%$ \\
\hline
\end{tabular}

Table 7: Tolerance Level of Ghanaian towards LGBTI Person

Source: Fieldwork, May to June 2018

\subsubsection{Age and Tolerance of LGBTIs}

Tolerance level among the youthful and adult population towards LGBTIs was low. While $41 \%$ and $51 \%$ of Ghanaians within the age bracket of 18-28 and 29-39 respectively, will "socially shun" LGBTI person, another $43 \%$ and $48 \%$ of the adult population aged 40-50 and 51-61 will also do so. Only 11\% of individuals, 62 years and above will "treat just like any heterosexual”. Refer to Fig. 1.

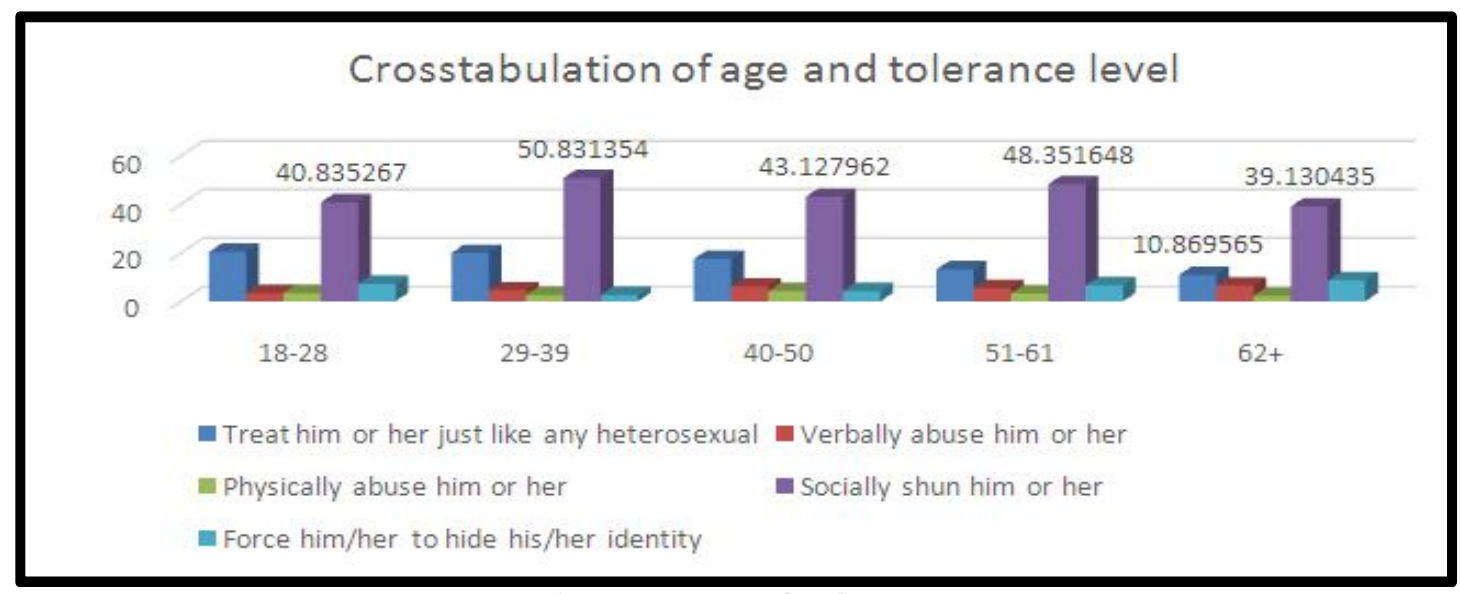

Figure 1: Age and Tolerance

Source: Fieldwork, May to June 2018

\subsubsection{Gender and Tolerance of LGBTIs}

Both the male and female population are less tolerant of LGBTI persons. Marginally more females (46.5\%) compared to male (44\%) will "socially shun" an LGBTI person. However, 50\% of transgender will "treat LGBTIs just like any heterosexual". Refer to Fig. 2.

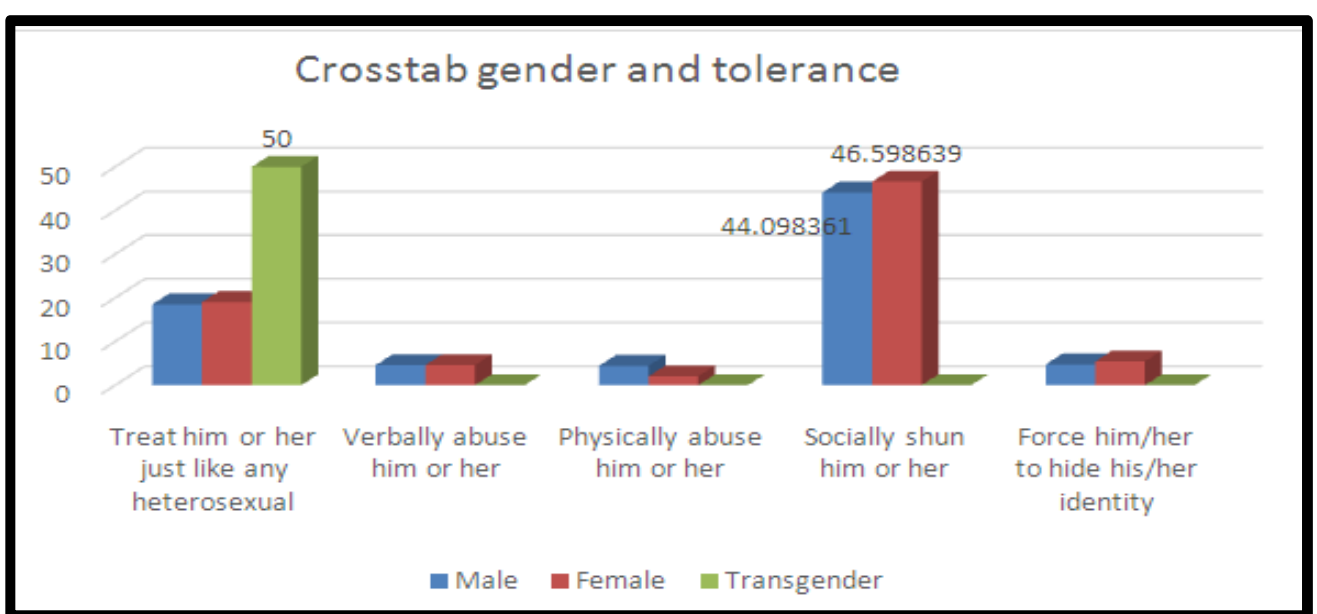

Figure 2: Genders and Tolerance of LGBTI Persons

Source: Fieldwork, May to June 2018 


\subsubsection{Education and Tolerance of LGBTIs}

Educational attainment and differences in attitudes are less significant factors in shaping peoples' perceptions about LGBTIs. Intolerance is more pronounced among citizens with basic education background (49.34\%) and secondary education background (47.50\%). However, $28.35 \%$ of the citizens with tertiary education background will treat an LGBTI "just like any heterosexual". Overall, $45.23 \%$ of the citizens with no formal education will "socially shun" an LGBTI. In a quantitative study conducted on the attitudes of the students of the Ghana Technology University towards homosexuality, Allotey also found out that students expressed high levels of negative attitudes towards homosexuality (Allotey, 2015; OtiBoadi, et al., 2014). Haruna also revealed that perceptions and level of tolerance of students towards homosexuality is negative (Haruna, 2015).Refer to Fig. 3.

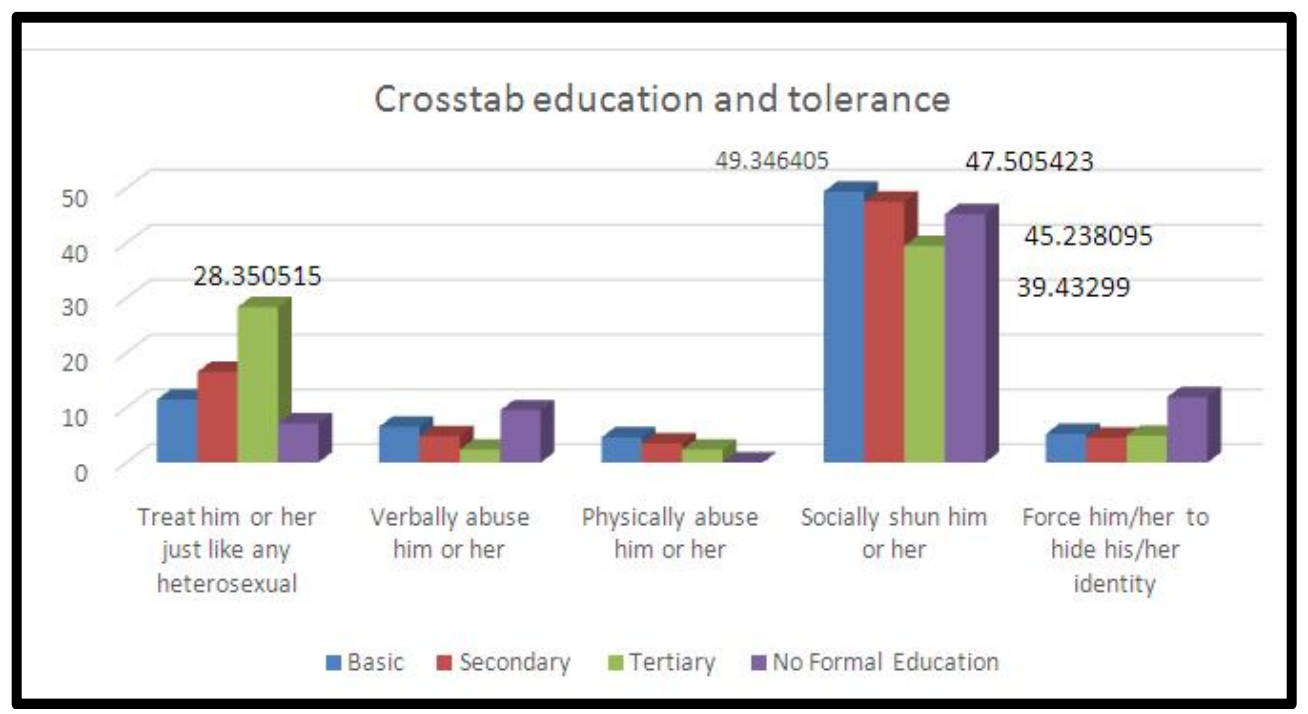

Figure 3: Education and Tolerance of LGBTI Persons

Source: Fieldwork, May to June 2018

\subsubsection{Religion and Tolerance of LGBTIs}

Discussions on the rights of LGBTIs transcend political, social, cultural and religious spectrum, but more so on the Constitution as the building block for the protection of citizens' rights. The study established a strong correlation between religion and the rights of LGBTIs. The findings show that religion is a major predictor and significantly influences people's attitudes towards LGBTIs. A high number of citizens Moslems (58.7\%), Traditionalists (53.8\%) and Christians (42.45\%) will "socially shun" an LGBTI. On the other hand, only 10.9\% Moslems, 7.6\% Traditionalists and 20.7\% Christians will treat an LGBTI "just like any heterosexual". Besides, a high majority of the citizens (33\%) will "socially shun" an LGBTI based on cultural values and $32.14 \%$ on personal values Refer to Fig. 4.

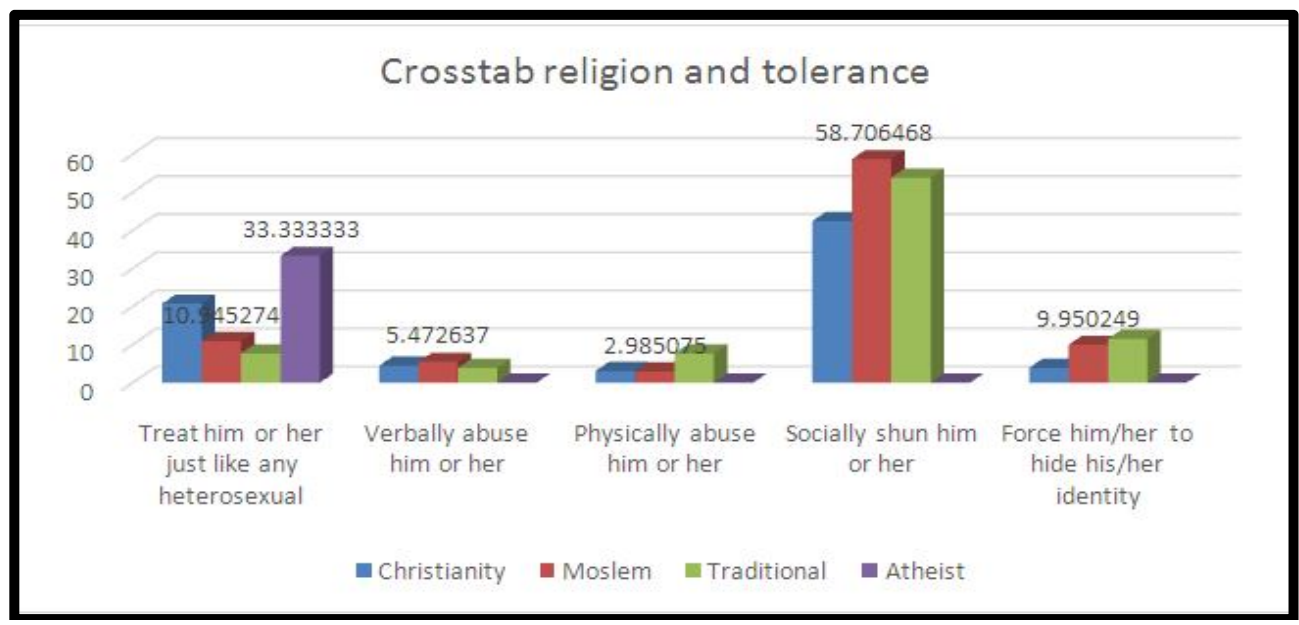

Figure 4: Religion and Tolerance of LGBTI Persons

Source: Fieldwork, May to June 2018

\subsubsection{Comfort and Association with LGBTIs}

On average, $80.1 \%$ of the citizens are "very uncomfortable" associating themselves with LGBTIs. The degree of discomfort was equally significant across the study regions, with Western region being the highest (90\%). Refer to Table 8. 


\begin{tabular}{|c|c|c|c|c|c|c|}
\hline \multicolumn{2}{|c|}{} & $\begin{array}{c}\text { Very } \\
\text { Comfortable }\end{array}$ & Comfortable & $\begin{array}{c}\text { Very } \\
\text { Uncomfortable }\end{array}$ & Uncomfortable & \\
\hline \multirow{3}{*}{ Region: } & Greater Accra & $6.3 \%$ & $20.0 \%$ & $44.3 \%$ & $29.3 \%$ & $100.0 \%$ \\
\cline { 2 - 7 } & Ashanti & $4.4 \%$ & $16.9 \%$ & $43.1 \%$ & $35.6 \%$ & $100.0 \%$ \\
\cline { 2 - 7 } & Northern & $1.7 \%$ & $9.4 \%$ & $55.6 \%$ & $33.3 \%$ & $100.0 \%$ \\
\cline { 2 - 7 } & Volta & $2.2 \%$ & $22.8 \%$ & $33.9 \%$ & $41.1 \%$ & $100.0 \%$ \\
\cline { 2 - 7 } & Western & $1.7 \%$ & $8.3 \%$ & $49.4 \%$ & $40.6 \%$ & $100.0 \%$ \\
\hline \multicolumn{2}{|l}{ Total } & $3.8 \%$ & $16.2 \%$ & $44.8 \%$ & $35.3 \%$ & $100.0 \%$ \\
\hline
\end{tabular}

Table 8: Comfort and Association with LGBTI Person

Source: Fieldwork, May to June 2018

\subsubsection{Discrimination against LGBTIs on Social Services and Economic Opportunities}

The survey sampled peoples' opinion on LGBTIs' access to basic social services and economic opportunities such as education, health care, religious association, job search, public and private (corporate) appointments. A significant number of citizens (36.3\%) are of the opinion that an LGBTI should be discriminated against in job search, 10\% indicated that they should be discriminated against religious association and $9.16 \%$ said LGBTIs should be denied public appointment. This finding is corroborated by the US Human Rights Country report 2014 which highlights that LGBTIs in Ghana face widespread discrimination in employment and education, as well as police harassment (USA, 2014).

\subsubsection{The Rights of LGBT Persons to Hold Public Meetings}

A greater number of the citizens (87.3\%) are of the opinion that LGBTIs should not be allowed to hold public meetings to discuss LGBTI issues. Refer to Table 9.

\begin{tabular}{|c|c|c|c|c|}
\hline \multicolumn{2}{|c|}{} & Yes & No & \\
\hline \multirow{3}{*}{ Region: } & Greater Accra & $13.0 \%$ & $87.0 \%$ & $100.0 \%$ \\
\cline { 2 - 5 } & Ashanti & $13.1 \%$ & $86.9 \%$ & $100.0 \%$ \\
\cline { 2 - 5 } & Northern & $8.9 \%$ & $91.1 \%$ & $100.0 \%$ \\
\cline { 2 - 5 } & Volta & $19.4 \%$ & $80.6 \%$ & $100.0 \%$ \\
\cline { 2 - 5 } & Western & $8.3 \%$ & $91.7 \%$ & $100.0 \%$ \\
\hline \multicolumn{2}{|c|}{ Total } & $12.7 \%$ & $87.3 \%$ & $100.0 \%$ \\
\hline
\end{tabular}

Table 9: Right of LGBTI Persons to Holding Public Meetings

Source: Fieldwork, May to June, 2018

4.6. Equal Treatment by All

A significant percentage 34.7 "disagree across the study region that LGBTIs should be treated equally as heterosexuals. Refer to Table 10.

\begin{tabular}{|c|c|c|c|c|c|c|}
\hline \multicolumn{2}{|c|}{} & $\begin{array}{c}\text { Strongly } \\
\text { Agree }\end{array}$ & Agree & $\begin{array}{c}\text { Strongly } \\
\text { Disagree }\end{array}$ & Disagree & \\
\hline \multirow{2}{*}{$\begin{array}{c}\text { Region } \\
:\end{array}$} & Greater Accra & $12.7 \%$ & $24.3 \%$ & $23.7 \%$ & $39.3 \%$ & $100.0 \%$ \\
\cline { 2 - 7 } & Ashanti & $14.7 \%$ & $33.1 \%$ & $16.7 \%$ & $35.6 \%$ & $100.0 \%$ \\
\cline { 2 - 7 } & Northern & $5.6 \%$ & $40.0 \%$ & $12.8 \%$ & $41.7 \%$ & $100.0 \%$ \\
\cline { 2 - 7 } & Volta & $4.4 \%$ & $33.9 \%$ & $35.0 \%$ & $26.7 \%$ & $100.0 \%$ \\
\cline { 2 - 7 } & Western & $8.9 \%$ & $18.9 \%$ & $46.1 \%$ & $26.1 \%$ & $100.0 \%$ \\
\hline \multicolumn{2}{|c|}{ Total } & $10.4 \%$ & $29.9 \%$ & $25.0 \%$ & $34.7 \%$ & $100.0 \%$ \\
\hline
\end{tabular}

Table 10: LGBTI Persons Deserve Equal Treatment as Heterosexuals

Source: Fieldwork, May to June, 2018

\subsubsection{Protection and Mob Injustice against LGBTIs}

A high number of the citizens (97.6\%) indicated that the police have a responsibility to protect every citizen against mob injustice. Also $61.4 \%$ of the citizens "strongly agree" that any person who engages in mob activity should be brought to justice. However, $12.3 \%$ of the citizens "strongly disagree" that the police should protect LGBTIs against mob injustice. Refer to Table 11,12 and 13. The UNHCR asserts that in more than 70 countries worldwide the criminalization of same-sex relations exposes millions of LGBTIs to the risk of discrimination, harassment, victimization, arrest, imprisonment, and in some cases execution (UNHCR, 2010). 


\begin{tabular}{|c|c|c|c|c|}
\hline \multicolumn{2}{|c|}{} & Yes & No & \\
\hline Region: & Greater Accra & $97.7 \%$ & $2.3 \%$ & $100.0 \%$ \\
\cline { 2 - 5 } & Ashanti & $96.7 \%$ & $3.3 \%$ & $100.0 \%$ \\
\cline { 2 - 5 } & Northern & $100.0 \%$ & & $100.0 \%$ \\
\cline { 2 - 5 } & Volta & $95.0 \%$ & $5.0 \%$ & $100.0 \%$ \\
\cline { 2 - 5 } & Western & $99.4 \%$ & $.6 \%$ & $100.0 \%$ \\
\hline \multicolumn{2}{|c|}{ Total } & $97.6 \%$ & $2.4 \%$ & $100.0 \%$ \\
\hline
\end{tabular}

Table 11: Mob Injustice and the Law

Source: Fieldwork, May to June, 2018

\begin{tabular}{|c|c|c|c|c|c|c|c|}
\hline \multicolumn{2}{|c|}{} & $\begin{array}{c}\text { Strongly } \\
\text { Agree }\end{array}$ & Agree & $\begin{array}{c}\text { Strongly } \\
\text { Disagree }\end{array}$ & Disagree & $\begin{array}{c}\text { Don't } \\
\text { Care }\end{array}$ & \\
\hline \multirow{2}{*}{$\begin{array}{c}\text { Region } \\
:\end{array}$} & Greater Accra & $72.0 \%$ & $19.3 \%$ & $3.0 \%$ & $3.0 \%$ & $2.7 \%$ & $100.0 \%$ \\
\cline { 2 - 8 } & Ashanti & $48.1 \%$ & $45.3 \%$ & $1.1 \%$ & $5.0 \%$ & $.6 \%$ & $100.0 \%$ \\
\cline { 2 - 8 } & Northern & $61.1 \%$ & $35.6 \%$ & & $2.2 \%$ & $1.1 \%$ & $100.0 \%$ \\
\cline { 2 - 8 } & Volta & $63.9 \%$ & $30.6 \%$ & $5.0 \%$ & & $.6 \%$ & $100.0 \%$ \\
\cline { 2 - 8 } & Western & $68.3 \%$ & $27.2 \%$ & $1.7 \%$ & $1.7 \%$ & $1.1 \%$ & $100.0 \%$ \\
\hline \multicolumn{2}{|c|}{ Total } & $61.4 \%$ & $32.4 \%$ & $2.1 \%$ & $2.8 \%$ & $1.3 \%$ & $100.0 \%$ \\
\hline
\end{tabular}

Table 12: Police Responsibility to Protect Every Citizen against Mob Injustice Source: Fieldwork, May to June 2018

\begin{tabular}{|c|c|c|c|c|c|c|c|}
\hline \multicolumn{2}{|c|}{} & $\begin{array}{c}\text { Strongly } \\
\text { Agree }\end{array}$ & Agree & $\begin{array}{c}\text { Strongly } \\
\text { Disagree }\end{array}$ & Disagree & $\begin{array}{c}\text { Don't } \\
\text { Know }\end{array}$ & \\
\hline \multirow{2}{*}{$\begin{array}{c}\text { Region } \\
:\end{array}$} & Greater Accra & $36.7 \%$ & $25.7 \%$ & $9.7 \%$ & $12.3 \%$ & $15.7 \%$ & $100.0 \%$ \\
\cline { 2 - 8 } & Ashanti & $33.9 \%$ & $41.1 \%$ & $6.4 \%$ & $16.7 \%$ & $1.9 \%$ & $100.0 \%$ \\
\cline { 2 - 8 } & Northern & $22.8 \%$ & $55.0 \%$ & $2.8 \%$ & $8.3 \%$ & $11.1 \%$ & $100.0 \%$ \\
\cline { 2 - 8 } & Volta & $17.8 \%$ & $42.8 \%$ & $14.4 \%$ & $14.4 \%$ & $10.6 \%$ & $100.0 \%$ \\
\cline { 2 - 8 } & Western & $36.1 \%$ & $48.3 \%$ & $7.8 \%$ & $5.6 \%$ & $2.2 \%$ & $100.0 \%$ \\
\hline \multicolumn{2}{|c|}{ Total } & $30.8 \%$ & $40.7 \%$ & $8.1 \%$ & $12.3 \%$ & $8.1 \%$ & $100.0 \%$ \\
\hline
\end{tabular}

Table 13: Police Have a Responsibility to Protect LGBTI Persons against Mob Injustice

Source: Fieldwork, May to June, 2018

\subsubsection{LGBTI and Homophobic Statements by State Officials}

Approximately $75.5 \%$ of the respondents indicated that homophobic statement by individual state officials should be "applauded". The findings re-emphasize the entrenched labeling of same-sex identity of LGBTIs. Awondo et al., argued that the debate around homosexuality in Africa particularly encourages a stereotypical image devoid of the internal debate and disagreements among Africans on the subject of homosexuality (Awondo, Geschiere, \& Reid, 2012; Awondo,2010). Refer to Table 14.

\begin{tabular}{|c|c|c|c|c|}
\hline \multicolumn{2}{|c|}{} & Applauded & Condemned & \\
\hline \multirow{3}{*}{ Region: } & Greater Accra & $55.3 \%$ & $44.7 \%$ & $100.0 \%$ \\
\cline { 2 - 5 } & Ashanti & $85.3 \%$ & $14.7 \%$ & $100.0 \%$ \\
\cline { 2 - 5 } & Northern & $73.3 \%$ & $26.7 \%$ & $100.0 \%$ \\
\cline { 2 - 5 } & Volta & $78.9 \%$ & $21.1 \%$ & $100.0 \%$ \\
\cline { 2 - 5 } & Western & $88.3 \%$ & $11.7 \%$ & $100.0 \%$ \\
\hline \multicolumn{2}{|c|}{ Total } & $75.5 \%$ & $24.5 \%$ & $100.0 \%$ \\
\hline
\end{tabular}

Table 14: Homophobic Statements against LGBTI

Source: Fieldwork, May to June, 2018

\subsubsection{Accessing Emergency Health Treatment from a Perceived LGBTI Medical Doctor/ Nurse}

A high percentage of the population (32.5) indicated that they will not receive emergency medical treatment from a known LGBTI nurse and/ or medical doctor. However, $67 \%$ indicated that they will do so. Also $56.39 \%$ of females will decline medical service from a nurse and/ or medical doctor perceived to be LGBTI, compared with $50.79 \%$ males who will do so. Again, while 100\% Atheists will access emergency medical care from a known LGBTI medical health professional, $50 \%$ traditionalists will not do so. And 50\% Moslems and 40.11\% Christians will also not access emergency medical care. 
Also, the aged population between the age bracket of 51-61 and $62+$ representing $44.15 \%$ and $42.42 \%$ respectively will not access an emergency medical health service from LGBTI nurse or medical doctor.

\section{Conclusions}

Citizens' knowledge of the fundamental human rights of all persons in the 1992 Constitution of Ghana and the subject of LGBTI is high. Awareness of LGBTIs can be found in the communities, neighborhoods, workplaces, commercial settings and schools. This corroborates Allotey's findings that homosexuality and its practice is not as invisible and alien to the Ghanaian culture (Allotey, 2015; Asante and Roberts, 2014; Dankwa, 2009; Ofori, 2014).

The study also established a strong correlation between religion and people's orientations towards the rights of LGBTIs. Besides, the study further revealed that, adherence to culture and traditions, and personal orientation of people significantly mold the values and opinions of heterosexuals towards LGBTI issues in Ghana. Similar to the findings of Herek, and Adamczyk and Pitt, religious and traditional ideologies are the strongest determinants of people's attitudes towards homosexuality (Adamczyk and Pitt 2009; Molamba BA 2012; Tan, 2012; Oti-Boadi, Agbakpe et al., 2014; Ofori, 2014). While some argued that homosexuality should be seen in the context of marriage, others think it should be treated in the context of lifestyle.

The Ghanaian media is a major platform for transmitting information on LGBTIs, with radio constituting $86 \%$. Arguably, media discussions and publications have been one-sided which often sparks adverse public debates on LGBTI issues. This corroborates Quist-Adade, Bates et al., argument that media publications present a challenge for objective analysis of LGBTI issues (Quist-Adade et al., 2014).

Again, a culture of homophobia exists in Ghana towards LGBTI issues, exhibited by hate speech openly expressed by the majority of citizens, including state officials. This often incites discrimination and violence against LGBTIs with reported cases of mob injustice in some communities. Cognitive dissonance of heterosexuals on the sexual orientation of LGBTI is reasonably high. The rights of LGBTIs are perceived by many as not in consonance with values, traditions and orientations of majority of the citizens. In addition, sexual orientation and identity of LGBTI is exercised mostly surreptitiously for fear of physical attacks and persecution.

\section{Recommendations}

The findings of the survey are intended to inform the implementation of the UPR recommendations accepted by Ghana during the review of its human rights record in 2008, 2012 and 2017. In 2017, Ghana accepted recommendations to provide equal protection of the law from violence to all persons including members of the LGBTI community. The paper therefore recommends the following that: 1) public education of the understanding of the distinction between the rights of the sexual orientation of LGBTIs and perceived acts is crucial to equal protection of the law from violence and discrimination. 2) Also, state institutions such as the police, CHRAJ, and National Commission for Civic Education (NCCE) to be equipped to educate citizens on Ghana's commitments under the UPR mechanism to protect the fundamental human rights of every person as enshrined in both domestic laws and international human rights instruments. 3) CHRAJ should continue to implement the Discrimination Reporting System in order to tackle stigmatization and discrimination of the most vulnerable groups in the society, and 4) civil society organisations, media and other rights-monitors should use the findings to monitor Government's commitments to protect the rights, safety and security of all citizens including LGBTIs in Ghana.

\section{References}

i. Adamczyk and Pitt (2009). The controversy of homosexuality: a critical look at the issues that make legalizing homosexuality in Malawi difficult.

ii. Allotey, N. M., (2015) Perceptions of Youth towards Homosexuality in Ghana, Faculty of Psychology, Department of Health Promotion and Development, unpublished Mphil thesis, pg.1-10.

iii. Asante, G., \& Roberts, M. N. (2014). Reliving Oppression: Becoming Black, Becoming Gay. In S. C. Howard (Ed.), Critical Articulations of Race, Gender, and Sexual Orientation: Lexington Books.

iv. Amnesty International Ghana, 2018.

v. Awondo, P., Geschiere, P., \& Reid, G. (2012). Homophobic Africa? Toward A More Nuanced View. African Studies Review, 55 (3), 145. See also Awondo, P. (2010). The politicisation of sexuality and rise of homosexual movements in post-colonial Cameroon. Review of African Political Economy, 37(125), 315-328. doi: 10.1080/ 03056244.2010.510624

vi. Berlin, I. (1959). Two Concepts of Liberty, Reprinted from Four Essays on Liberty, Oxford University Press, pp. 1535.

vii. Centre for Democracy and Development (2017), AfroBarometer, Let the People have a say, Round 7, Accra

viii. Child Rights Connect, www.childrightsconnect.org accessed on June 15, 2018

ix. Daumann, F. (2007). Evolution and the rule of law: Hayek's concept of liberal order reconsidered, Journal of Libertarian Studies, Volume 21, No. 4, pp. 123-50.

x. Ewan, P. (2007) 'Deepening the Human Security Debate: Beyond the Politics of Conceptual Clarification', Politics, 27 (3), pp. 182-189.

xi. Foucault, M. (1978). History of Sexuality Volume 1: An introduction, Pantheon Books, New York

xii. Friedrich Ebert Stiftung, (2008). The HCR Universal Periodic Review: A preliminary assessment, Dialogue on Globalisation, Briefing Paper, FES Geneva.

xiii. Ghana Statistical Service. (2013b). 2010 Population and Housing Census, Regional Analytical Report. Accra. 
xiv. Haruna, U. (2015). Stirring the Hornet's Nest: a Study of Student's Awareness, Perception and Tolerance of Homosexuality in a Ghanaian University. Journal of Sociological Research, 6(1).

xv. Horn, S. S. (2006). Heterosexual adolescents' and young adults' beliefs and attitudes about homosexuality and gay and lesbian peers. Cognitive Development, 21(4), 420 - 440.

xvi. Herek, G. M. (1988). Heterosexuals' attitudes toward lesbians and gay men: Correlates and gender differences. The Journal of Sex Research, 25(4), 451-477. doi: 10.1080/ 00224498809551476

xvii. Hayek, F.A. (1967b). "The Theory of Complex Phenomena." In F.A. Hayek, Studies in

xviii. Hayek, F. A. (1960). The Constitution of Liberty. Chicago: University of Chicago Press

xix. International Journal of Linguistics, Literature and Culture (Linqua - IJLLC, 1(2).

xx. International Council on Human Rights policy, 2009

xxi. Lindlof, T. R., \& Taylor, B. C. (2010). Qualitative communication research methods: Sage.

xxii. Nyeck, S. N., \& Epprecht, M. (2013). Sexual Diversity in Africa: Politics, Theory, and Citizenship: MQUP.Ofori, E. (2014). Perception of Students on the Practices of homosexuality amongst students in the Cape Coast. See also Whitley (2000).

xxiii. Philosophy, Politics, and Economics. Chicago: University of Chicago Press: 22-42.

xxiv. Palidda, and Axworthy, L. (2010) 'Human Security and Global Governance: Putting People First', Global Governance, 7(1), pp. 19-23.

xxv. Phillips, D. O. (2000). Constituting the Global Gay: Issues of Individual Subjectivity and Sexuality in Southern Africa. In D. Herman \& C. Stychin (Eds.), Sexuality in the Legal Arena. See also Phillips, 1997, p. 485-489.

xxvi. Pew Research Centre. (2013). Growing Support for Gay Marriage: Changed Minds and Changing Demographics (pp. 2-20): The Pew Research Centre for the People \& The Press.

xxvii. Sen, A. (2000). 'Why Human Security?' presentation at the International Symposium on Human Security

xxviii. Singh, J. (2014). Human Security: A Theoretical Analysis. Inter. J. Polit. Sci. Develop. 2(8): 175-179.

xxix. State of the Union (2010) State of the Union Report.pp.1-10. See also www.stateoftheunionafrica.net

xxx. Tan, 2012 in Oti-Boadi, Agbakpe et al., 2014).

xxxi. Tankebe, J (2010) Testing the Effects of Public Experiences of Police Corruption in Ghana,

xxxii. The Constitutional Review Commission Report. 2010. Available at http:/ / www.ghana.gov.gh/ images/ documents/ crc_report.pdf retrieved on May 282018

xxxiii. The Humanist Association of Ghana (HAG)

xxxiv. UNHCR. (2010). Tackling discrimination on grounds of sexual orientation and gender identity. Retrieved from http:// www.ohchr.org/ Documents/ Issues/ Discrimination/ LGBT discrimination A4.pdf. See also International Council on Human Rights policy, 2009

xxxv. UN Human Rights Council (2017).Report of the Working Group on the Universal Periodic Review, Ghana.

xxxvi. UNDP (1994). Human Development Report, UNDP

xxxvii. UN Human Rights Council (Dec 2017). Report of the Working Group on the Universal Periodic Review, Ghana

xxxviii. UNHCR, (2017) Ghana 3rd Cycle Universal Periodic Review, Sexual Orientation and Gender Identity (SOGI)

xxxix. UNHCR. (2010). Tackling discrimination on grounds of sexual orientation and gender identity. from http:// www.ohchr.org/ Documents/Issues/ Discrimination/_LGBT_discrimination_A4.pdf accessed on June 2018, and International Council on Human Rights policy, 2009.

xl. UN Human Rights, UPR, A Practical Guide for Civil Society, Office of the Commissioner, July 2014).

xli. http:/ / www.ohchr.org/ EN/ HRBodies/ UPR/ Pages/ NgosNhris.aspx. Accessed on May 2018

xlii. UN Human Rights Council (Dec 2017) Report of the Working Group on the Universal Periodic Review, Ghana, United Nations, General Assembly A/ HRC/ $37 / 7$

xliii. http:// webtv.un.org/ watch/ consideration-of-ghana-upr-report-35th-meeting-22nd-regular-session-humanrights-council accessed June 2018

xliv. Quist-Adade, C., Bates, F., \& Wathanafa, N. (2014). Homosexuality in the Ghanaian Media: A Preliminary Survey. Republic of Ghana, 1992 Republican Constitution, Chapter 5

xlv. World Health Organisation, 2012AS. 